\title{
Rules tightened for aboriginal studies
}

Canada's main funding agency for health research has adopted ethics guidelines for studies involving the estimated one million indigenous people in the country.

Researchers and tribal leaders are optimistic that the guidelines will help to speed up the investigation of health problems among Canadian aboriginals, whose life expectancy has been estimated to be between five and eight years shorter than that of other Canadians. This is due in part to a greater susceptibility to diabetes, cardiovascular disease and mental-health problems.

The guidelines - the first to offer a comprehensive framework for

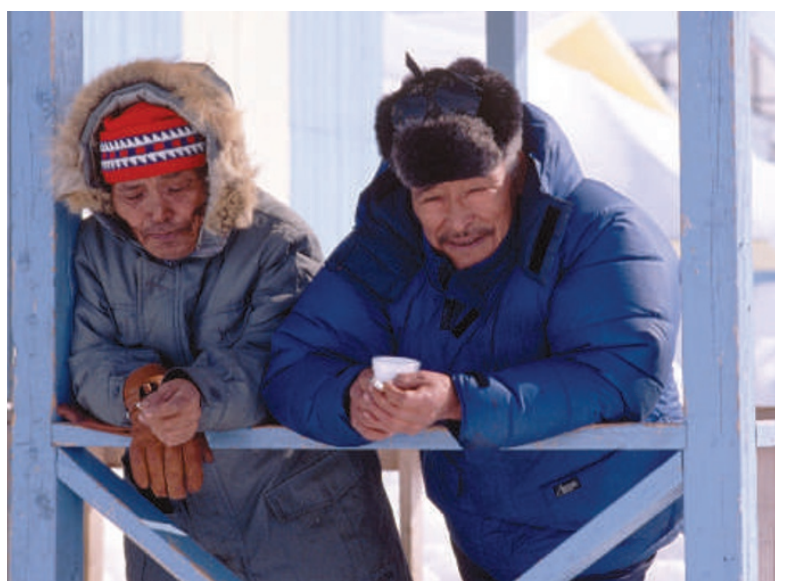

Improved rules could speed up research into indigenous health. researchers working with aboriginal communities - state that scientists should focus on the collective interests of the community in planning their studies. For example, they must obtain consent for projects from the community involved, as well as from individuals. Biological samples should be considered "on loan" to the researcher, and the community should have the opportunity to review the conclusions drawn from the data.

"This is a big step forward," says Alan Bernstein, president of the Canadian Institutes of Health Research (CIHR), the main federal funding agency for health research and the author of the guidelines.

Until now, Canadian researchers working with indigenous people have relied on the guidance in a 1998 human research ethics statement issued by the Tri-Council (see Nature 395, 420; 1998), a body comprising three federal research agencies, of which the CIHR is one. Ethicists have said that its comments on indigenous peoples are inadequate, and agencies have long recognized the need to beef up the guidance.

"Standards were quite uneven across the country," says Jeff Reading, scientific director of the Institute of Aboriginal Peoples' Health (IAPH), which is part of the CIHR.

The guidelines were prepared by the Ethics Office of the CIHR and the IAPH, in partnership with the aboriginal communities of First Nations, Inuit and Métis. A working group surveyed the research guidelines developed in other countries and by aboriginal groups to explore the issues raised by research involving aboriginal people.

Although the recommendations are not legally binding, health researchers and institutions funded by the CIHR will be required to follow them.

The relationship between researchers and aboriginal communities has been problematic in the past. So-called fly-in researchers would come into communities, take samples, and never be seen again. The issue was thrust into the public eye in 2000, when the Nuu-chah-nulth, a First Nations community living on Vancouver Island, British Columbia, discovered that DNA samples collected between 1982 and 1985 to study the high incidence of rheumatic disease in the community had been later used in other research projects, including an anthropological study that was not part of the original consent (R. H. Ward et al. Proc. Natl Acad. Sci. USA 88, 8720-8724; 1991).

Global genetics projects such as the Human Genome Diversity Project and the Genographic Project, which both explore human origins and migrations, have also met with opposition from aboriginal groups, partly because there were no obvious benefits to the community.

Hannah Hoag

\section{Canadian government pushed to protect land}

Scientists from around the world have urged the Canadian government to take action to protect its northern landscapes. They claim that development is threatening one of the last great tracts of woods and wetlands on Earth.

In a 14 May letter delivered to Bob Mills, chair of the environment committee in Canada's House of Commons, 1,521 scientists from 51 countries asked the Canadian government to support the principles that were laid out in the 2003 Boreal Forest Conservation Framework.

That agreement between industry, indigenous people and conservation groups said that at least half of the 6 million square kilometres of boreal region should be off-limits to development, and the rest should be managed sustainably. The boreal region contains forest, wetland and

\section{"Provincial governments} are left free to support unlimited development."

other landscapes, and covers much of northern Canada.

The campaigners say that the region is crucial to ecosystems worldwide. It serves as a breeding ground for 3 billion migratory birds, and is an important source of fresh water and the largest terrestrial carbon sink on Earth. So far, it has sequestered more than 180 billion tonnes of carbon.

One of the letter's signatories is Ken Caldeira, a climate modeller at the Carnegie Institution based at Stanford, California, who last month published a study suggesting that the total destruction of Canada's boreal forests would actually ease global warming (see Nature, doi:10.1038/news070409-2; 2007). Some say that press coverage of the study raised public doubts about the need to conserve the boreal region.
"It is certainly something we are struggling with," says Jeff Wells, science adviser for the International Boreal Conservation campaign in Seattle, Washington.

Canadian prime minister Stephen Harper has said that he will designate almost 100,000 square kilometres of land in the Northwest Territories as protected, but those deals have yet to be finalized. That leaves provincial governments free to support unlimited development, says David Schindler, a boreal ecologist at the University of Alberta in Edmonton. Erika Check 